\title{
Further observations on Nellymyces megaceros and its parasite - Rozellopsis uliginosa sp. nov.
}

\author{
ANDRZEJ BATKO \\ Institute of Botany, Warsaw University, Al. Ujazdowskie 4, 00-478 Warsaw, Poland
}

Batko A., Further observations on Nellymyces megaceros and its parasite - Rozellopsis uliginosa sp. nov., Acta Mycol. 13 (2):313-324, 1977.

The rhipidiaceous fungus Nellymyces megaceros Batko, described in the author's previous study has been again found at the type locality in 1971. Observations carried out on this material in the course of fungus population development, have shown that all of the smooth zoosporangia occuring in the 1970 (type) material had been attacked by a holocarpid biflagellate parasitic fungus, and had their openings slightly modified. In the present study, the author describes healthy smooth sporangia of $N$. megaceros, and zoospores forming within them, he describes the above-mentioned parasitic fungus - Rozellopsis uliginosa sp. nov., erects a hypothesis explaining the specific characters of the life cycle of $N$. megaceros and populations dynamics in this parasite-host system, and resolves the controversal questions of taxonomy of holocarpic parasitic chytrids and lagenidial fungi. In connection with the latter question, two new genera have been established - Skirgiellia and Skirgiellopsis.

\section{INTRODUCTION}

Since the discovery of Nellymyces megaceros in 1970, I have been searching for that fungus each year on deciduous tree branches and twigs which have fallen into water, within the area of the Kampinos National Park. In spite of that, I managed to spot it only twice; once in 1971 , and once in 1973 . The 1973 occurence was very sparse, anyway, and I managed to find only a few thalli with spiny sporangia in May of that year. Since then, the fungus fungus has not appeared, either at its type locality, or at any other similar site within the Park area. This may be attributed to the extremely low level of ground water in the southern part of the Park during the recent years and to the progressing 
pollution of my fungus type locality, by sewage draining from a nearby hospital. This puts a question mark over the future axistence of the entire ecosystem of the small alder forest described in the previous study (B a tk o 1971).

In 1970, I discovered the fungus in May, and its population, quite abundant and extensive, survived until the middle of June. The following year, I began searching in January, but until the end of March, I could find only a few tufts of Blastocladia globosa Kanouse (in fact, a new species in Poland's mycoflora) and sparse filaments of Apodachlya sp., upon alder, hazel, and hornbeam branches submerged under the ice. The first sparse thalli of. N. megaceros did not appear until the first decade of April, on submerged alder branches. These thalli, slender and little branched out toward the apex, carried initially only smooth zoosporangia in quantities of 5 to 23. Around April 20, they were replaced in the population by dimorphic thalli described in the previous study (1.c., Fig. 1), carrying almost exclusively spiny zoosporangia or parthenosporangia. The slender thalli with smooth zoosporangia mentioned above, would appear to be, therefore, a juvenile form of the fungus, transforming later on into one of the forms represented in the adult population.

A study of the dimorphic thalli collected after April 20 of 1971, did not produce any significant differences when compare with the originai description of the population of May 1970. The juvenile thalli mentioned above, however, supplied new data concerning the morphology of smooth zoosporangia, zoospores, and zoosporogenesis, which has put last year's research in a new light. The first remarkable difference was that the evacuated zoosporangia in newly collected had a short evacuation tube at the top, straight, as in Fig 2, or curved, as in Fig. 4, while the few evacuated zoosporangia encountered the previous year had an apical pore (1.c., Fig. 2 b). In new material, immature zoosporangia terminated in a protruding hemispherical papilla, while in the previous year's material, the apex was broadly rounded (l.c., Fig. 1 c, 2 d). I did not succeed last year in observing the evacuation of zoospores from the sporangia, and the measurements were taken from a group of zoospores free floating in water on a microscope slide, among thalli of the fungus under consideration. I have concluded, that the zoospores originated from one of the sporangia in the slide, but $\mathrm{i}$ was unable to observe which one it was. I described the zoospores as "almost spherical, 9.3-11.2 $\mu \mathrm{m}$ in diameter, with two laterally inserted and oppositely directed flagella" A comparison with the 1971 zoospores, which were formed in a rather aboundant quantities, points to the fact that the previous year's zoospo- 
res were observed during a stage immediately preceding their encystation (see Fig. 3a in the present study and Fig. $2 \mathrm{~b}$ in the preceding one). Hence, the 1971 material made it possible to correct the original diagnosis in the part pertaining to the morphology of smooth zoosporangia and zoospores, while it put the life cycle of the discussed fungus in a new light. Furthemore, it raised the problem of the true nature of the smooth zoosporangia without papillae and with the simple apical pore, which were observed the previous year and described in the preceding study. Further observations of the $N$. megaceros population developing during April and May of 1971 made the solution of this problem possible: the sporangia proved to have been attacked by a holocarpic parasitic fungus, which has formed within them enormous quantities of small, biflagellate zoospores. The parasite did not cause deformation of host sporangia, but altered somewhat its development, preventing the formation of prominent apical papilla. Such infected sporangia appeared in the 1971 material before April 20, and by the beginning of May, healthy sporangia could not be found in the samples.

\section{ZOOSPORANGIAL AND ZOOSPORE MORPHOLOGY OF THE HOST}

The smooth Nellymyces megaceros sporangia (Fig. 1) are oval or obovoid, their dimensions are $50-135 \times 30-54 \mu \mathrm{m}, 100 \times 42 \mu \mathrm{m}$ on the average. The apex of a mature sporangium terminates in a hemispherical papilla about 9-12.5 $\mu \mathrm{m}$ in diameter. Prior to the release of zoospores, the papilla becomes slightly elongated, and at its apex a pore is formed the diameter of the papilla, which transforms in this way into an izodiametric evacuation tube $15-25 \mu \mathrm{m}$ in length (Fig. 2). Diplanetic, primary zoospores (Fig. 3 a) form into a zoosporangium and are ovoid, narrowing toward the front, $11-14 \times 7.2-8.6 \mu \mathrm{m}$, with a granular cytoplasm generally containing 1 or 2 oil drops, slightly flattened and grooved on the underside; from the anterior end of the groove, two oppositely directed flagella of unequal length grow out (the anterior one, around $15 \mu \mathrm{m}$; posterior one, around $25 \mu \mathrm{m}$ ); not very motile when riped, they exit slowy one at a time and shortly become encysted. The encysted zoospores (Fig. $3 \mathrm{c}$ ) are rounded 8.8-9.5 $\mu \mathrm{m}$ in diameter, their plasma usually containing an oil drop or a refractive globule, they germinate with a long, thin germ, which may open up in a pore at its apex, releasing a secondary zoospore (Fig. 3 d). Frequently, only a portion of the primary zoospores evacuate the zoosporangium, while the rest become encysted in situ, and germinates with long germ tubes growing out through the evacuation tube (Fig. 4). 


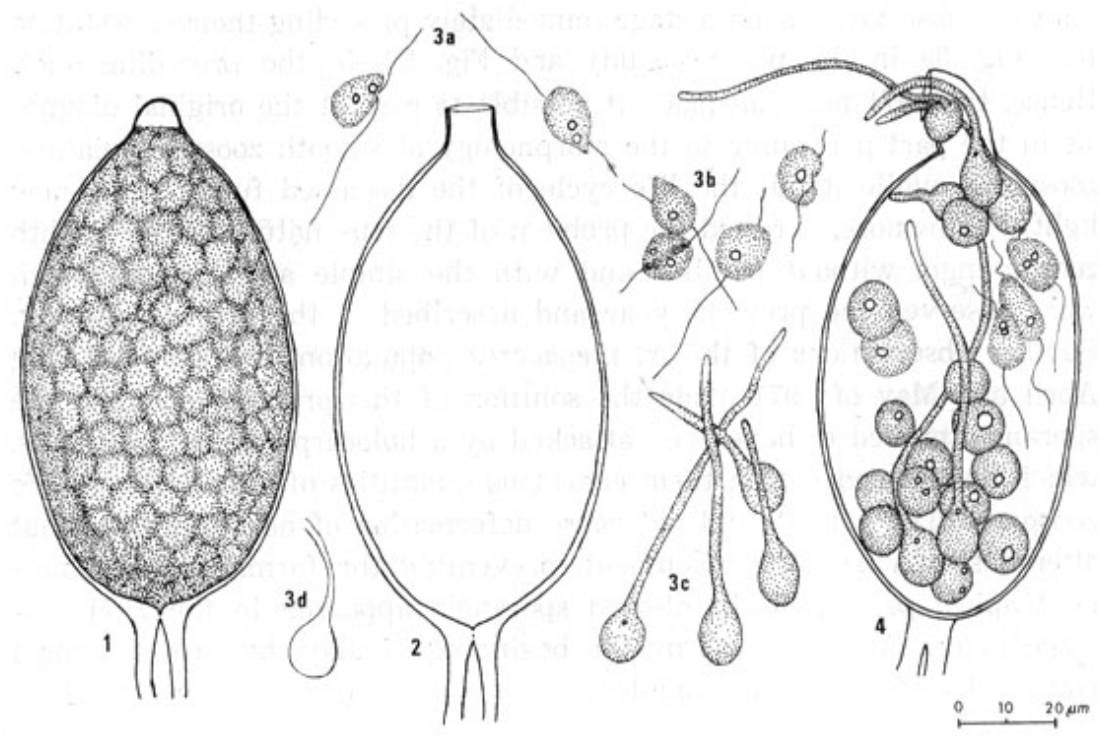

Fig. 1. A healthy young smooth sporangium of Nellymyces megaceros in the stage of zoospore cleavage; note the prominent hemispherical evacuation papilla

Fig. 2. Evacuated healthy sporangium of Nellymyces megaceros with a straight evacuation tube

Fig. 3. Active (a) and encysting (b) zoospores of Nellymyces megaceros; encysted zoospores with a germ (c); and an empty zoospore case with an evacuation tube, following the evacuation of the secondary zoospore (d)

Fig. 4. Zoosporangium of Nellymyces megaceros with a curved evacuation tube, with part of the zoospores still remaining inside; these are encysting in situ, some germinating with a long germ (evacuation tube), reaching out through the opening of the sporangium

\section{ZOOSPORANGIAL AND ZOOSPORE MORPHOLOGY AND TAXONOMY OF THE PARASITE}

Parasite infected smooth zoosporangia of Nellymyces megaceros do not form a protruding papilla. The parasite sporangium fills the host one so closely, that their walls are indistinguishable. Before reaching maturity, the contents of an infected zoosporangium become fragmented into a large number (several hundred) of particles, of which zoospores are formed. At the center of the maturing parasite sporangium, there is a hardly visible large vacuole, and the initially tightly-packed zoospores begin to move slightly at a certain time, then their total mass begins to spin within sporangium, slowy at first, then it loosens up and accelerates, and soon all zoospores are spinning rapidly and actively. Soon, the top wall of the sporangiumm becomes slightly protruding and dissolves 
rapidly. The zoospores exit singly, moving rapidly away from the zoosporangium.

According to Karling (1942 b) and Sparrow (1960), a fungus with such a characteristics belongs to the genus Rozellopsis Karling (1942 a). It differs from the two monocentric species included here, primarily by the taxonomic position of the host, since both the $R$. inflata (Butler) Karling and the $R$. waterhouseii Karling are found in the sporangia of Pythiaceae (Pythium, Zoophagus, Phytophthora sp. div.). Parasitic specialization of all holocarpic parasites (both uni- and biflagellate), with a thallus morphologically simplified to such a degree, is usually very high, and none of the known species of Rozellopsis, or Rozella Cornu were so far observed on hosts belonging to different families, while the majority of them occur on host fungi of a single genus. Therefore, the taxonomic position of the host of my parasite is by itself sufficient to consider it as a new species. In addition, there are significant differences in zoospore morphology, in the insertion of their flagella, in the parasite's effect upon the development of host thallus, etc. Therefore, I am describing it here as:

Rozellopsis uliginosa sp. nov.

Sporangium ad formam sporangii hospitis exacte conformans. Zoosporis ovoideis, globulo oleifero uno vel duobus et flagellis inaequalibus laterali insertis. Sporae perdurantes incognitae. Parasitica in sporangiis levibus Nellymycetis megaceroidis. In alnetis in silva Kampinos dicta, Polonia.

Iconotypus: figurae 5 a-c.

\section{LIFE CYCLE AND POPULATION DYNAMICS OF NELLYMYCES MEGACEROS}

A comparison of the results of observations of $N$. megaceros population studied during the two consecutive years, makes it possible to formulate a hypothesis explaining some of its particular characters. It appears that the fungus is adapted to existence under strong selection pressure exerted upon its population by the population of Rozellopsis uliginosa coexisting with it. As a result of such a pressure only the youngest thalli of the earliest, first generation (or generations) stand a chance of effectively disseminating their zoospores in a given year, and they are these thalli which form the active, smooth zoosporangia. The relatively rapid activation of the parasite population results in almost total infection of smooth zoosporangia produced later, which 

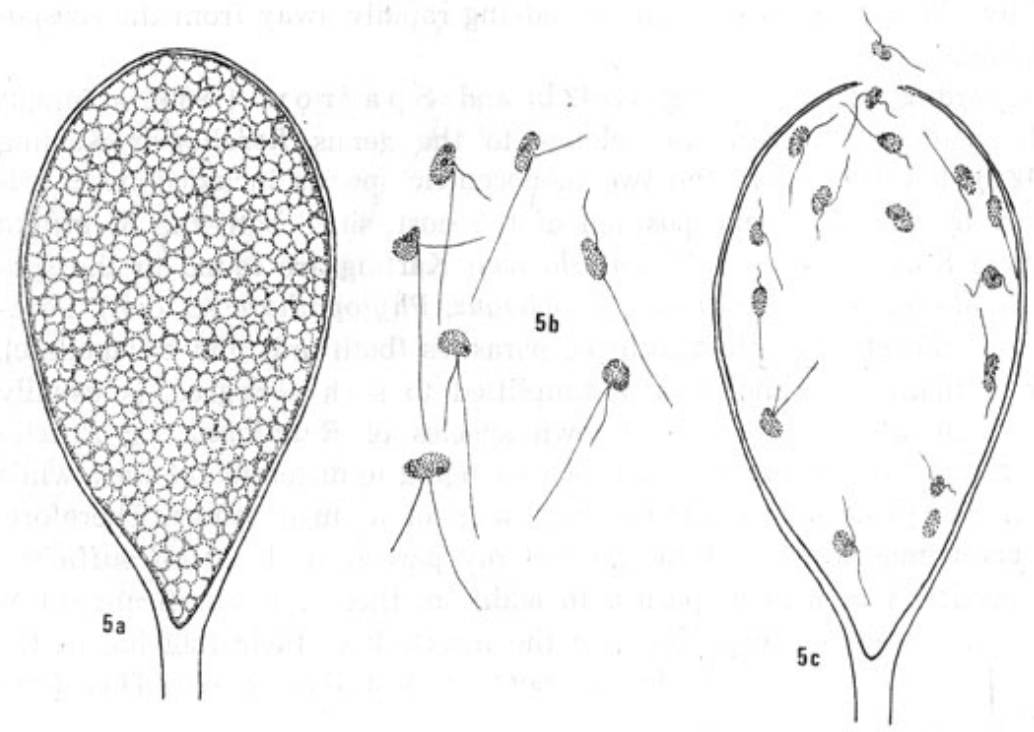

ABt. del.

Fig. 5. Sporangium of Rozellopsis uliginosa at the stage of zoospore cleavage within a smooth sporangium of Nellymyces megaceros; note the almost uniformly rounded apex of the host sporangium (a) (comp. Fig. 1); zoospores of Rozellopsis uligi nosa (b); the same sporangium at the stage of zoospores evacuation; note the large simple pore (c) (comp. Figs. 2, 3, and 5)

interrupts the further propagation of the host and prevents any increase in the number of thalli in its population. The defense reaction of host population is a change in the direction of further ontogeneses of thalli and the production of numerous parthenosporangia and spiny sporangia. The parthenospores make possible a certain degree of survival of the population until the following spring, and give rise to the new appearance of the fungus, while the role of the spiny sporangia is unknown.

These hypothesis explains the specific phenology of Nellymyces megaceros and its irregular appearances (even under favourable environmental conditions). Presumably, the host population "takes off" at a lower treshold of water temperature than does parasite population, but the difference is so slight, that only in years of ample precipitation and cool spring temperatures, can $N$. megaceros develop in significant numbers of thalli before its zoospores production is arrested by the parasite. The immature, young and sparse thalli with smooth zoosporangia only are rather inconspicous and little characteristics, hence they are apt to be overlooked and even to be confused with Apodachlya or Sapromyces 
thalli. It is only the dimorphic thalli of the later generations that are easily discernible, particularly when appearing in mass. It appears however, that such a mass occurence of the fungus, and hence, reneval of the spore stockpile in the bottom sediments of the pool, occurs not more often than once in a few years, under particularly favourable atmospheric conditions.

This hypothesis is sufficiently detailed and it leads to several possible test implications (in the sense imparted to this concept by $\mathrm{H} \mathrm{e} \mathrm{m} \mathrm{pel}$ 1966), hence, it may be considered to be a good working hypothesis for further study of the Nellymyces megaceros - Rozellopsis uliginosa system, unless the study is made impossible by the already mentioned dissipation of the environment by the drying up and sewage pollution of that part of the alder forest in the Kampinos National Park.

\section{REMARKS ON THE TAXONOMY AND NOMENCLATURE OF HOLOCARPIC PARASITIC PHYCOMYCETES}

Lower holocarpic zoosporic fungi, the zoosporangia of which do not have their own wall, or, whose wall is so fused with the host's wall, that it is indistinguishable from it under optical microscope, occur among uniflagellate (Rozella Cornu), as well as biflagellate (Rozellopsis) Phycomycetes. In either case, the monocentric as well as polycentric fungi are included in one and the same genus (see Sparrow 1960). This-leads to complications in identification, since the attribute of mono- or polycentricity serves the purpose of families distinction, not genera. Hence Sparrow hat arbitrarily included genus Rozella in the family Olpidiaceae grouping monocentric fungi, while he included Rozellopsis in the corresponding family Olpidiopsidaceae. This has resulted in the unidentificability of the polycentric Rozella and Rozellopsis species in his monograph, since in order to identify e.g. common Rozella septigena Cornu, one has to assume first the thesis "thallus forming a single sporangium" (in identifying the members of the family Olpidiaceae, p. 120 of op. cit.), and then the thesis: "thallus polysporangiate, that is, giving rise to sporangia which form linear conjoined segments (sori) within the host hyphae..." (op. cit., p. 168). A similar inconsistency can be found in the Sparrow's monograph in the identification of e.g. Rozellopsis septigena. On page 920 , in the "Key to the families of the Lagenidiales", we must assume, in spite of obvious facts, that "thallus always one-celled,..." only to observe in a short while (p. 923), this time in accordance with reality, that "sporangia septigenate (in linear series)...".

Such imperfections in the fundamental monograph for this area of mycology stem from inconsitent employment of one and the same cha- 
racters in the 'differentitation of subordinated taxons of different rank (e.g. simultaneously, families and contained within them genera). Therefore, the rank of diagnostic characters has to be strictly defined for a given group of fungi, and, in our case, its utility has to be limited to either the family or the genus level. There still remains the question: which of the two?

Apart from bringing out the rather numerous shortcomings in the logical structure of the most popular, at this time, classification of zoosporic fungi (presented in its classical form in the abovementioned Sparrows monograph), there has been an increasing tendency during the recent years to question its very principles, i.e. the assumed hierarchy of characters. In particular, the excessively high ranking of such morphological characteristics as the mode of sporangium opening, the morphology of the vegetative apparatus of eucarpic thalii, and the position of thallus in relation to substratum has been questioned (see e.g. Whiffen 1944; Karling 1966; Roane and Paterson 1974). With regard to that Roane and Paterson wrote: "Certain characteristics that have been used to distinguish taxa of chytrids are unreliable because they are too variable. These include the position of the thallus, position of resting spore, and the presence of catenulate apophyses. Certain other characteristics appear to be constant and thus useful in chytrid taxonomy; namely, size of sporangia, size of resting spores, and the type of thallus development" (underlinning mine - A.B.). Moreover, it is their opinion that, "...the placing together of genera with the same type of thallus development may aid in developing a natural classification of the chytrids" (p. 102). Also in Karling's key "the criteria of thallus organization, monocentricity, polycentricity, holocarpy, eucarpy, development and morphology are given prime recognition..." (1966, p. 2). Hence, since the publication of the Whiffen study (1944), numerous authors have been inclined to attribute a high (family) rank to characters connected with ontogenesis, in the classification of Chytridiomycetes and other zoosporic fungi, even to recognize this class of characters as superordinate to purely morphological (static) characters.

The recognition of the high rank of developmental features, connected with the type of ontogeny, is quite common not only among the students of lower fungi, but of lower eucaryota in general. We encounter it in algology, where the so-called morphological types of thalli or "grades of morphological advance" are commonly used for order distinction (F o t t 1974). In spite of the name, these categories are not purely morphological, since their definition contain information pertaining to the type of ontogenesis. In a series of theoretical works the author has 
attempted to justify the correctenss of such a standpoint by the deduction from the theory of evolution, resting on the assumptions of phylogenetic taxonomy, and pointing out that the essential changes in the structure of ontogenesis were connected to the so-called arogenetic, or progressive evolutionary changes in the history of a given group of organisms (B a t k o 1974, 1976, 1978). Hence, theoretical considerations, as well as empirical data, would lead one to recognize the capacity of holocarpis fungus for vegetative divisions in the course of ontogenesis (which leads to the polycentricity of thalli) to be a characteristic of family, rather than species, rank.

Two conclusions proceed from the above considerations: 1) assuming the accepted doctrine of zoosporic fungi classification, it is incorrect to maintain the genera, which group together species with different types of ontogenesis; 2) as a result of that, such genera should be subdivided in such a way, that it would be possible to distribute them in a system of families distinguished according to the above principle.

Among the four species included by Cornu (1872) in the genus Rozella at the time of its erection, three are monocentric and one $R$. septigena - is polycentric. This quantitative relation is enough to suggest that the lectotype of this genus should be chosen from among monocentric species (i.e. in order to restrict the number of new combi-. nations, which must be erected then). Moreover, the ordering of species descriptions in the Cornu study points also to the fact that he considered the polycentric species to be, in a sense, an aberrative one. Among the three monocentric species, one is quite rare ( $R$. apodyae-brachynematis Cornu), while another is a rare parasite of the rare host (R. rhipidii-spinosi Cornu on Araiospora spinosa Cornu). Therefore, I would suggest that the most common species in the New as well as the Old World, and the first one described by Cornu (in the sense of "page-priority") Rozella monoblepharidis-polymorphae Cornu - should be recognized as the lectotype of the genus Rozella. With regard to the fourth one among Cornu's species $-R$. septigena - I suggest the establishment of a new genus:

\section{Skirgiellia gen. nov.}

Ethymology: name given in honor of Prof. Alina Skirgiełło, the noted Polish mycologist.

Fungi in thallis ceterorum fungorum zoosporicorum parasitantes. Sporangia ad formam sporangii vel thalli partis hospitis exacte conformantes. Fungi polycentrici, thallus maturans in plurimas partes dissecans et in sorum zoosporangiorum transiens. Zoosporae uno flagello posteriore posito. Sporae perdurantes in sporangiis formantur. 
Typus generis: Skirgiellia septigena (Cornu) Batko, comb. nov.

Basonymum: Rozella septigena Cornu, Ann. Sci. nat., Bot., 15: 163, pl. 6. 1872, non Fischer, Jahrb, wiss. Bot., 13: 321, pl. 14, fig. 19; pl. 15, fig. 20-28. 1882 .

Among fungi later described as Rozella species, two more should be referred to the new genus:

Skirgiellia achlyae (Shanor) Batko, comb. nov.

Basonymum: Rozella achlyae Shanor, J. Elisha Mitchell Sci. Soc., 58: 100, pl. 17. 1942.

Skirgiellia allomycis (Foust) Batko, comb. nov.

Basonymum: Rozella allomycis Foust, J. Elisha Mitchell Sci. Soc., 53: 198, pl. 22-23. 1937.

For holocarpic parasites with biflagellate zoospores, usually referred to the Olpidiopsidaceae (i.e. S p a r row 1960; B atk o 1975), an analogical operation should be performed. Among the four species included by $\mathrm{K}$ arling $(1942 \mathrm{a}, \mathrm{c})$ in the genus Rozellopsis at the time of its erection, two are monocentric ( $R$. inflata (Butler) Karling and $R$. waterhousei Karling), and two other polycentric. From among two monocentric ones, more common and, therefore, somewhat better known is the former one. Because of that, I propose that this species - Rozellopsis inflata (Butler) Karling - should be recognized as the lectotype of the genus Rozellopsis.

From among the two polycentric species hitherto referred to the genus Rozellopsis, one - namely, $R$. fischeri C e jp (1959) is of rather complicated nomenclature. The fungus was discovered by $\mathrm{F}$ is cher (1882) and mistakenly identified as Rozella septigena Cornu. Karling has used the same specific epithet "septigena" in the new combination, but Cejp has shown, that in this situation it becomes invalid, therefore - he suggested an nomen novum: Rozellopsis fischeri Cejp. The second one was erected by Fischer (op. cit.) and described under the name Rozella simulans. From these two species, $R$. fischeri is more perfectly studied (Prow s e 1951), its septate thallus is known to arise from a single zoospore, and I select it to be the type of new genus:

\section{Skirgiellopsis gen. nov.}

Ethymology: the name stresses the convergent similarity with the genus Skirgiellia Batko.

Fungi in thallis ceterorum fungorum zoosporicorum parasitantes. Sporangia ad formam sporangii vel thalli partis hospitis exacte conforman. tes. Fungi polycentrici, thallus maturans in plurimas partes dissecans 
et in sorum zoosporangiorum transiens. Zoosporae flagellis inequalibus duobus. Sporae perdurantes in sporangiis formantur.

Typus generis: Skirgiellopsis fischeri (Cejp) Batko, comb. nov.

Basonymum: Rozellopsis fischeri Cejp, Oomycetes I:, Nakl. CSAV, Praha. 1959.

$\equiv$ Rozellopsis septigena Karling, Amer. J. Bot. 29: 34. 1942 (nom. inv.).

In addition, the new genus should also include:

Skirgiellopsis simulans (Fischer) Batko, comb. nov.

Basonymum: Rozella simulans Fischer, Jahrb. Wiss. Bot., 13: 365. 1882.

$\equiv$ Rozellopsis simulans (Fischer) Karling, Amer. J. Bot. 29: 34. 1942.

The establishment of the new genera Skirgiellia and Skirgiellopsis makes it possible to remove the above mentioned inconsistency in classification of holocarpic zoosporic fungi, since in the new interpretation the genera Rozella and Rozellopsis fit well into families Olpidiaceae and Olpidiopsidaceae, respectively, while the new genera fit equally well into families Achlyogetonaceae and Sirolpidiaceae, respectively. This makes possible the construction of truely functional identification keys for these fungi, keys available for the use of non-specialized naturalists, hence the fulfillment of one of the essential duties of mycological systematics.

Acknowledgment

The author wishes to thank professor Wladyslaw Matuszkiewicz for preparation of latin diagnoses.

\author{
Dalsze badania nad Nellymyces megaceros \\ i jego pasożytem-Rozellopsis uliginosa sp. nov.
}

Streszczenie

\begin{abstract}
Opisany w poprzedniej pracy (B a t k o 1971) grzyb z rodziny Rhipidiaceae Nellymyces megaceros Batko został odnaleziony powtórnie w stanowisku typowym w roku 1971. Badanie nowego materiału wykazało, że materiał typowy był porażony przez pasożyta z grupy holokarpicznych grzybów o pływkach dwuwiciowych, który odkształcał przebieg rozwoju zarodni gładkich żywiciela i nie dopuszczał do sformułowania rurki ujściowej. Materiał zebrany w 1971 roku umożliwił uściślenie diagnozy $N$. megaceros w części odnoszącej się do gładkich zarodni pływkowych, opisanie wspomnianego pasożyta jako nowego dla nauki (Rozellopsis uliginosa sp. nov.) oraz rozstrzygnięcie niekonsekwencji logicznych w przyjętej obecnie klasyfikacji holokarpicznych gatunków Phycomycetes poprzez utworzenie dwóch nowych rodzajów: Skirgiellia i Skiergiellopsis.
\end{abstract}




\section{REFERENCES}

B a tko A., 1971, Nellymyces megaceros gen. et sp. nov. - a new aquatic phycomycete related to Aqualinderella and Araiospora. Acta Mycol. 7: 251-268.

B atko A., 1974, Filogeneza a struktury taksonomiczne Entomophthoraceae. [In:] Cz. Nowiński (ed.), „Ewolucja Biologiczna”, Ossolineum, Wroclaw: 209-305.

B a t k o A., 1975, Zarys Hydromikologii, PWN, Warszawa, 478 pp.

B a tko A., 1976, Struktura ontogenezy, filogeneza a taksonomia Volvocales. [In:] Cz. Nowiński (ed.), „Ewolucja Biologiczna”, Ossolineum, Wrocław: 165-215.

B atko A., 1978, Przeksztalcenia struktury ontogenezy w toku ewolucji postępowej u niższych roślin. [In:] Cz. Nowiński (ed.), „Ewolucja Biologiczna”, Ossolineum, Wroclaw: (in press).

C e j p K., 1959, Oomycetes I. Flora CSR, B. 2. Praha.

C ornu M., 1872, Monographie des Saprolégniées; étude physiologique et systématique. Ann. Sci. nat. Bot., V, 15: 1-198, pls. 1-7.

F i s cher A., 1882, Untersuchungen über die Parasiten der Saprolegnieen. Jahrb. wiss. Bot. 13: 286-371, pls. 13-15.

F o t t B., 1974, The phylogeny of eucaryotic algae. Taxon 23: 446-461.

H e m pel C. G., 1966. Philosophy of natural science. Prentice Hall, Inc., Englewood Cliffs, N.J.

Karling J. S., 1942a, Parasitism among the chytrids. Amer. J. Bot. 29: 24-35.

Karling J. S., 1942b, The simple holocarpic biflagellate Phycomycetes. Published by the Author, N. Y., pp. 123.

Karling J. S., 1942c, A synopsis of Rozella and Rozellopsis. Mycologia 34: 193-208.

K a r ling J. S., 1966, The chytrids of India with a supplement of other zoosporic fungi. Beih. Sydowia, ser. II, 6: 1-125.

Prowse G. A., 1951, On Rozellopsis septigena. Trans. Brit. mycol. Soc. 34: 400-405.

Roane M. K. and R. A. Paterson, 1974, Some aspects of morphology and development in the Chytridiales. Mycologia 66: 147-164.

Sparrow F. K., Jr., 1960, Aquatic Phycomycetes, 2nd ed., Ann Arbor 1187 pp. . Michigan.

Whiffen A. J., 1944, A discussion of taxonomic criteria in the Chytridiales, Farlowia 1: 583-597. 